\title{
Christa Thomsen*
}

\section{Public Sector CSR Communication: A Dialogical Approach}

\begin{abstract}
Public sector organisations have different communication needs from private sector organisations. For example, they quite often have programmes aimed at behaviour changes, challenging their ability to choose the strategy which best suit their purpose. Dialogue is often considered a strategic tool which can lead to organisational gains such as motivation, learning, development, collaboration, etc. This article examines the role of dialogue in Danish public sector Corporate Social Responsibility (CSR) Communication aimed at behaviour change and employer mobilisation. The focus is on central government CSR communication strategies and how these strategies are implemented by a local government. It is argued that public actors' (government departments, State agencies and local bodies) communication with employers on CSR is behaviour change communication and that it is possible to analyse this communication within the framework of a dialogue analysis model developed in linguistics. A theoretical dialogue-change model is proposed as an alternative to how government departments, State agencies and local bodies can mobilize employers.
\end{abstract}

\section{Introduction}

People working in the public sector have different communication needs from those in private sector organisations. In particular, they have programmes aimed at disseminating information about legal and regulatory requirements and aimed at behaviour change. Programmes on Corporate Social Responsibility (CSR) are examples of programmes aimed at behaviour change. According to management literature, social responsibility is not a new concept (Friedman, 1970; Freeman 1984; Carroll 1999; Waddock 2004; Kakabadse et al. 2005; Freeman/Velamuri 2006). A number of large companies have assumed some degree

\footnotetext{
* Christa Thomsen

ASB Centre for Business Communication

Aarhus School of Business, University of Aarhus

Fuglesangs Allé 4

DK-8210 Aarhus $V$

ct@asb.dk
}

Hermes - Journal of Language and Communication Studies no 38-2007 
of social responsibility in the past. Their interest was mainly focused on the social sphere and was entirely voluntary. Corporate philanthropy is a good example of this. What is new is the increased interest in the concept. In Denmark and in Europe, the notion of social responsibility has been brought forward and cultivated actively since the mid-nineties by the Danish State and the European Commission. At the same time employees, consumers and other stakeholders have grown more aware of social, economic and environmental issues, and many companies believe that it pays to show a social conscience or that it may be too expensive not to do so. Therefore, they react by introducing a CSR policy. However, introducing a model for social responsibility and new practices related to areas such as absence due to illness or job training offers to persons with reduced working capabilities requires preparation. Habits and organisation culture must be changed. It is no longer enough to inform employers and employees. They must be committed, and they must be able to act in a new context. This is when the concept of dialogue becomes relevant.

Dialogue is often considered a strategic tool which can lead to organisational gains such as motivation, learning, development, collaboration, etc. (Bohm 1996; Ellinor/Gerard 1998; Isaacs 1999). In government departments, State agencies and local bodies as for example the municipalities in Denmark the strategic role of dialogue is also increasing in social advisers' and job consultants' work where employers are expected to play a more and more active role as fellow players, dialogue partners or collaborators (Act on active social policy in 1998 and the "more people to work" reform in 2002, see e.g. Andersen/Pedersen 2000).

This article examines the role of dialogue in Danish public sector Corporate Social Responsibility (CSR) Communication, the perspective being behaviour change and employer mobilisation. The focus is on central government CSR strategies and how these strategies are implemented by local governments. It is argued theoretically that very long dialogues conducted in organisational settings such as the dialogue on CSR between people working in the public sector (Government departments, local bodies and State agencies) on the one hand and employers on the other hand fulfil the basic needs for dialogue, for example in turn-taking. They are also goal-oriented; the form or the course of events reflects the purpose of the dialogue which is seen here as 
behaviour change, employer mobilisation and supporting the development and the implementation of a social responsibility policy or model in Danish companies

Empirically, it is argued that the dialogue on CSR conducted in Denmark is initiated at a national level and pursued at a regional and local level in the form of public-private or social partnerships. At the regional and local levels, the public actor and the employer engaged in social partnerships have a clear role distribution when communicating CSR to employees and others. The public partner communicates the message or the purpose, whereas the private partner communicates the subject.

Why is this kind of analysis interesting? From a theoretical communication viewpoint, it is interesting because it challenges our notion of dialogue ${ }^{1}$. How can we describe very long dialogues conducted in organisational settings (Andersen/Thomsen, under peer review) or crosssector settings? Which theories and models can be used and what kind of data do we have? In this article the on-going dialogue on the social responsibility of companies initiated by the Danish Government in 1994 is used as an example of how the basic principles of a dialogue analysis model, here the hierarchical and functional dialogue analysis model developed in Geneva (Roulet et al. 1986), may be applied to very long cross-sector dialogues with more diffuse contours. The main theoretical challenge is the delimitation of the units and the establishment of the relations between the units - this is a challenge that has been taken up by linguists and others. See e.g. Nølke/Adam 2000.

From a practical viewpoint, the analysis is interesting because it can contribute to our knowledge of what is happening in the on-going dialogue between businesses and society. Is social responsibility a public policy concept or is it a company or market driven concept? (Bredgaard, 2004). Who controls the dialogue and who sets priorities? (Knudsen 2006). This is important knowledge for managers and others involved in CSR activities.

This article is based on information on the Danish social responsibility campaigns available on Danish ministerial websites and elsewhere as well as observations and conversations with the partners in a social

1 Dialogue is understood as an interaction through messages, i.e. as a complex and dynamic process where human beings make sense in their relationship with one another. For a more detailed discussion, see paragraph 1.1. 
partnership between the Danish rescue company Falck A/S, the municipality of Aarhus and the vocational rehabilitation centre Jobcenter Århus Nord, a partnership which has existed since 1999.

The organisation of the article is as follows. First, I discuss the challenges of dialogue analysis in my perspective which is the analysis of very long organisational and cross-sector dialogues. Next, I offer my case findings that shows that the dialogue on CSR is initiated at a national level and pursued at a regional and local level in the form of social partnerships. I explore the structure of the dialogue looking at the change process and the role distribution between the public actor and the employer when communicating CSR to employees and others. By way of conclusion, I sum up and make a few recommendations related to further research and the theoretical dialogue-change model which is proposed as an alternative to how government departments, State agencies and local bodies can mobilize employers.

\section{Dialogue Analysis}

In 1984 the PR researchers Grunig and Hunt argued that two-way symmetrical communication, here understood as dialogue, is the ideal communication form when a company wants to get into contact with the outside world (Christensen/Morsing 2005: 103 ff.). In a dialogue, two equal partners are those who have equal rights to expect that the partner will change behaviour if the right arguments for this are put forward. The overall purpose with a dialogue is to obtain mutual understanding between the company and its stakeholders and agreement on the subject or issue discussed. The basis of this model is negotiation and compromise. According to Grunig and Hunt, the two-way symmetrical communication model is not only more ethical, but also more efficient when it comes to the fulfilment of the aim of the company.

\subsection{What is dialogue?}

A dialogue can be defined as a verbal interaction between two or more persons who exchange words and turns of talk of which the length depends on the situation (Kerbrat-Orecchioni 1990: 15). In this article, I draw on linguistic knowledge about what a dialogue is in order to say something about very large turns of talk which I consider relevant for the interaction between public actors on the one hand and employers 
and employees on the other hand. This kind of interaction for example consists of turn-taking in the form of one or more questions raised at an opening seminar and another turn-taking in the form of answers to the questions raised. The questions and answers are related by expectations. Other channels than seminars are relevant, and this is why I propose to characterize the interaction form multi-medial.

In order for dialogue to make sense there must be some kind of coherence between the individual turns of talk. The dialogue partners must listen to each other and talk to each other. This means that the setting must allow the partners to do this. Besides, the dialogue partners must talk about something. For the social anthropologists E. Goffman (1974), P. Brown and S. Levinson (1990) a dialogue is a ritual activity with the overall aim to confirm and maintain a social relation. This purpose is more important for the progression of the dialogue than the actual communicative purpose. The dialogue partners are first and foremost preoccupied with not losing face and not threatening the face of the partner. Critical voices raise the question whether dialogues are possible in organisations ruled by economic rationality (such as Alrø/ Kristiansen 2004). My definition of the dialogue concept is very broad. A dialogue can for example be "asymmetrical” (Grunig/Hunt 1984), which means that the partners may signal some kind of distance for example by using formal expressions and/or "power". Whether the use of power is legitimate or not depends among other things on status and relations. The use of power can for example be considered legitimate if it is generally accepted.

There are various kinds of dialogues for example informal conversations, discussions, debates and interviews. Irrespective of what kind of dialogue we are talking about, the course of action depends on situational determinants such as the physical characteristics of the dialogue, i.e. time, place, channel and the participants in the dialogue - how many are there? What are their backgrounds, status and mutual relations? Who has taken the initiative to the dialogue, and who sits at the end of the table/has the power? The purpose of the dialogue is also an important determinant - is it to have a nice conversation or is it a negotiation? Are there several purposes for example an overall purpose and several minor purposes? Also duration, rhythm and contents/theme play a role. Finally, the course of a dialogue depends on the degree of formality and 
on the tone of voice. In principle, there is a scenario for each situation. For instance, we all have an idea of the scenario of a job interview.

In order to become a competent dialogue partner it is necessary to know the rules and the expectations which govern a dialogue. It can for example be useful to know the rules of linguistic politeness (Brown/ Levinson 1990) or social grammar (Petersen 2004) in order not to offend the dialogue partner or his or her moral sense. In general, the partners should know the framework or the context of the dialogue. It may be helpful to ask questions such as: who is my partner and what are our mutual relations? Are there several partners and/or stakeholders in the dialogue? What are the background and the purpose of the dialogue? Where and when will it take place? How long is it scheduled for? What characterizes the political, legal, academic or professional context of the dialogue? What are the social and cultural characteristics of the dialogue? (Frandsen/Halkier/Johansen 2002)

\subsection{Dialogue structure and function}

At surface level, all dialogues resemble more or less each other. The conversation analysts Sacks, Schegloff and Jefferson made an important discovery in 1974, namely that at surface level all verbal interactions consist of turns or contributions from the respective partners in the conversation. Furthermore, by studying interactions in details, they found that they are based upon so-called adjacency pairs. A question and an answer consist of such an adjacency pair as the construction is held together by the expectation of an answer. Added to this is the fact that some answers are preferred. Finally, conversation analysts have made the observation that almost all interactions are surrounded by an opening and a closing.

Conversations with a clear purpose, such as conversations conducted in an organisational context, have another common feature, namely goal-orientation. The Geneva School (Roulet et al. 1986) understands dialogue as a hierarchical or logical construction. According to this school, dialogue consists of units at different levels (for example a superior versus a subordinate exchange) which are tied together in different ways. The starting-point of the model is a conception of dialogue as negotiation. This means that a dialogue is not closed before the partners have reached an agreement, including an agreement on the fact that it 
is not possible to reach an agreement. This also means that a turn is not complete until it is as clearly formulated and motivated that the recipient is capable of answering. A simple constructed example may illustrate this:

(1)

1. A: Initiative Would you like to go to the cinema with me tomorrow?

2. B: Response It sounds like a great idea.

3. A: Evaluation Fine. I will pick you up at 7 PM.

In example (1) the request is immediately met making it possible to close the dialogue.

(2)

1. A: Initiative Would you like to go to the cinema with me tomorrow?

2. B: Response No, tomorrow I must prepare a meeting.

3. A: New initiative Alright then, what about Thursday?

4. B: Response Thursday is OK.

5. A: Evaluation Fine. I will pick you up at 7 PM.

In example (2) the request is not met in the first response. It is not until (A) has made his request in a new form that it is met, and the dialogue can be closed. In principle, there are no limits to the duration of a dialogue. The duration and the course of a dialogue depend on the kind of response given to the initiative. If an initiative, here a request, is immediately met, the dialogue is closed. If not, the dialogue will continue. The dialogue can also be closed if the originator realises that he cannot get on with his proposal which may result in a closing, such as: "Never mind, I will find someone else to go with me to the cinema". However, there are strategies for getting a positive answer immediately, for example a pre-sequence:

(3)

1. A: Initiative Do you have a day off this week?

2. B: Response Yes, on Thursday.

3. A: Initiative Alright then, would you like to go to the cinema with me on Thursday?

4. B: Response It sounds like a great idea.

5. A: Evaluation Fine, then I will pick you up at 7 PM. 
In this example the first question prepares the superior question which is "would you like to go to cinema with me?" This strategy can also be used as an efficient persuasion strategy. Once you have answered that you have a day off on Thursday, it may be difficult to refuse an invitation to the cinema. Pre-sequences of this type have an argumentative function (See e.g., Jackson/Jacobs 1980; Jacobs/Jackson 1989 and Thomsen 2000 for the theory and more examples).

According to the model, a good dialogue is characterised by the fact that the partners know their rights and duties. They have a right to speak, and they have a right to expect something from their dialogue partner. For example, they can expect an answer to a question. At the same time, they have duties such as listening to their dialogue partner. In an organisational context (goal-oriented dialogues) it is, furthermore, a requirement that good dialogues are not closed until the partners have reached an agreement, including an agreement on disagreeing.

The model gives rise to discussing the respective roles, tasks and strategies (for example preparation or not) of the partners which is interesting in my perspective. The roles of public and private partners are different which can be explained by the fact that they represent different sectors with different framework conditions. In order to understand what is going on in cross-sector dialogues, it is useful to remember that the public sector can be characterized as formalised and non-profit oriented and the private sector as formalised and profit-oriented (Klausen 2001: $92 \mathrm{ff}$ ). Thus, the communication of the private sector and that of the public sector also differ both in terms of contents and form.

Below, I use the basic principles of the model to describe the crosssector dialogue on CSR initiated by the Danish government in 1994. In practice, it can be difficult to delimit the units or the turns. However, one possibility is to regard a meeting between two or more persons at a certain place and at a certain time as a unit (Kerbrat-Orecchioni 1990: $214 \mathrm{ff}$.). Furthermore, a unit can be defined by its topic as topic shifts can mark the transition to a new unit.

\section{The dialogue on CSR is initiated at the national level: national campaigns and networks}

The dialogue on CSR was (formally) initiated or reinitiated if we consider CSR as an old phenomenon in new and perhaps more attractive 
clothes by the Danish Ministry for Social Affairs in 1994 with the launch of the national campaign "It concerns us all". As early as in 1992 and 1993, the Ministry had made a strategic decision to generate support for public-private or social partnerships with outreach to employer and labour organisations. The central message of the campaign was that public authorities alone should not take on responsibility for all parts of societal life. Especially business was encouraged to play a more active role in coming up with new solutions to the increasing social problems. Social partnerships were seen as an innovative tool for solving difficult social problems (for example marginalised and long-term unemployed social clients) by bringing forward a solution that combined social policy and labour market policy. The argument was that by joining partnerships companies would maintain legitimacy, trustworthiness and approval from their stakeholders (Hardis 2004: 513). This argument was later adopted by the European Commission (2001). Thus, rather than mandating or regulating employers to participate, the campaign set out to change managers' attitudes (Holt 1998, p. 9-10).

To implement the campaign the Minister of social affairs, Karen Jespersen, formed a group of about 15 large employers called the National Network of Business Leaders who has come to speak today with one voice for all businesses. Furthermore, five Regional Networks of Business Leaders were created, thus carrying the national project to a regional and local level. Each regional network had - and still has - an "inspirator" who reaches out to firms and persuades them to create jobs and training for the long-term unemployed and for people with reduced working capacities. In 1995, FormidlingsCenter Aarhus, FCA (now Center for Aktiv BeskæftigelsesIndsats, CABI), an independent institution, was established by the Danish Government and employer and labour organisations in response to the growing national interest in the inclusive labour market. In 1998, The Copenhagen Centre, an independent think tank, was established by the Danish Government in response to the growing international interest in new social partnerships and corporate social responsibility initiatives. Martin (2006) has examined employer mobilisation in Denmark and the United Kingdom and concludes among others that these local business mobilisation efforts seem to have been especially important in the Danish case and have contributed to higher participation rates in active social policy in Den- 
mark. Strong structural imperatives to take action and benefits structures of the policies also explain the high participation rate.

Yet, there seem to be significant differences in the strategies of local government (Damgaard 2000). Some municipalities have focused on network-building, whereas others have restricted employer outreach efforts to media advertising and contacts by e-mail. Figure (1) illustrates the structure and the contents of the dialogue between the Danish State (Ministry for Social Affairs and since 2001 the Ministry for Employment $^{2}$ ) and Danish employers.

\begin{tabular}{|c|c|c|}
\hline \multirow[b]{2}{*}{ A } & \multicolumn{2}{|l|}{ Dialogue structure } \\
\hline & $\begin{array}{l}\text { Initiative (1994): Ministry for Social } \\
\text { Affairs (since } 2001 \text { persued by the } \\
\text { Ministry for Employment) }\end{array}$ & $\begin{array}{l}\text { National Campaign "It Concerns Us All" } \\
\text { Structural imperatives to take action and } \\
\text { benefits structures (especially the local } \\
\text { Coordination Committees for preventive } \\
\text { labour market measures) }\end{array}$ \\
\hline B & $\begin{array}{l}\text { Reaction (1994-2000): } \\
\text { Players on the Inclusive Labour } \\
\text { Market: }\end{array}$ & $\begin{array}{l}\text { Practicing CSR defined as job retention, } \\
\text { job integration and activities aimed at } \\
\text { preventing accidents, etc. }\end{array}$ \\
\hline B1 & $\begin{array}{l}\text { Employers, National Network of } \\
\text { Business Leaders, five Regional } \\
\text { Networks of Business Leaders }\end{array}$ & \\
\hline B2 & Counties and municipalities & \\
\hline B3 & $\begin{array}{l}\text { Independent institutions such as FCA } \\
\text { and TCC and others }\end{array}$ & \\
\hline A & Evaluation/closing (2000) & Evaluation of the campaign \\
\hline A & $\begin{array}{l}\text { New initiative based on the previous } \\
\text { initiative (2004) }\end{array}$ & Campaign "Dialogue with the Minister" \\
\hline
\end{tabular}

Figure 1: Structure and contents of the dialogue on CSR between the Danish Ministry for Social Affairs, The Danish Ministry for Employment and Danish employers.

2 The initiative on CSR in Small and Medium-Sized Companies taken by the Danish Commerce and Companies Agency, Ministry of Economic and Business Affairs, in 2005 is not included as their definition of CSR is broader than the inclusive labour market. Thus, it is a somewhat different initiative involving other dialogue partners than the ones addressed by the Ministry for Social Affairs and the Ministry for Employment. 
As mentioned above, Danish municipalities were encouraged to enter social partnerships. The concept was introduced as a strategy for the Inclusive Labour Market in 1994 by Karen Jespersen, former Danish Minister of social affairs. At a European level, the strategy for social responsibility was determined in the Green Paper "Promoting a European framework for corporate social responsibility" published by the EU Commission in 2001. The background for this was an acknowledgement that the problems of the welfare society could no longer by solved at state-level alone. Other players besides the municipalities should help support the necessary changes of the welfare society, including companies.

The strategy resulted in a new legislation and in various support structures. The basic principle was and still is "voluntary activities", and the strategy can best be characterized as a network strategy (Sepstrup 2006: 229-234). It is based upon personal, local and relevant communication, and it requires that the target group (players on the Inclusive Labour Market, primarily municipalities, counties and companies) shares some common networks or pass specific "sluices", so that it can be reached via these networks or at the sluices. Relevant networks and sluices are: the local Coordination Committees for preventive labour market measures, the Danish National Network of Business Leaders

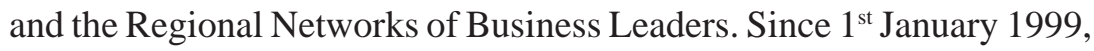
all Danish municipalities must have a Coordination Committee according to the Danish law on legal rights and administration in social affairs, whereas the company networks are voluntary. With the labour market reform "More People to Work" and the latest legislation in the area (Act on active labour market measures of 10th of June 2003 and Act on the responsibility for and the administration of active labour market measures of 10th of June 2003), the strategy now comprises even more players (Andersen/Pedersen 2006).

\section{4. ... and pursued at the regional and local level: public-private/social partnerships}

As already mentioned, the strategy chosen by the public sector in 1994 was local social partnerships. A social partnership can be defined as "People and organisations from some combination of public, business and civil constituencies who engage in voluntary, mutually beneficial, 
innovative relationships to address common societal aims through combining their resources and competencies" (Nelson and Zadek, 2000: 1415). According to this definition social partnerships rest on six basic principles: societal goal, innovation, cross-sector collaboration, voluntary and mutually beneficial activities and a combination of resources and competencies. Social partnerships may consist of public players at a local, national, European or international level; private players, such as companies or branch organisations, and civil players, such as associations, unions, teaching institutions, national and international NGO's, etc. As far as the purpose is concerned, some partnerships only focus on job prevention and job retention, whereas others also focus on job integration. The cooperation forms vary and depend on types of partners and the interests these partners may have. In my description below of the who, what and where of the dialogue on CSR at a local and regional level, I will concentrate on local partnerships.

Research shows that collaboration projects between the public sector and the private sector are most efficient when there is a clear purpose, a joint mission, a joint value creation, mutual benefits, effective communication and engagement from both sides. This includes a shared "we"identity (Hardis 2003; Wymer et al. 2003). Local partnership agreements are primarily settled between municipalities and companies. However, also local coordination committees, unemployment funds, vocational rehabilitation centres, professional organisations, practising doctors, etc. are seen as partners. In practice, it is often the municipalities or one of the cooperation partners of the municipality (for example a vocational rehabilitation centre or another player) who initiate a partnership agreement. According to the act on responsibility for and administration of active employment measures, the Danish municipalities are responsible for supporting and activating unemployed and noninsured people. They are also responsible for vocational rehabilitation measures and for deciding who should be offered special considerations jobs. We see that the social partnership as dialogue partner (in dialogue with stakeholders such as NGO's, the community, unions, etc.) is a complex mechanism which speaks with different voices. The message it sends is inevitably ambiguous in one way or another, and it is up to the recipient to interpret it and make sense of it.

On the Inclusive Labour Market, the topics are job retention and job integration. Job retention is primarily based upon the loyalty of the 
working environments and their responsibilities towards their employees. Job integration is about the openness of the working environments for people outside the labour market and about the efforts made by the municipalities to help people outside the labour market getting a job. The Inclusive Labour Market expresses the vision that people with a reduced working capability is given the possibility to use their abilities and participate on the labour market. This means that the social partnership as some kind of organisation primarily caters to people in two situations: 1) employed people who risk being dismissed as a result of for example illness or old age, and who may find it difficult to get a new job and 2) unemployed people who have difficulties entering the labour market because of long-term unemployment, reduced working capability, ethnicity, etc. In order to reach the direct target group of a model for social responsibility, i.e. people who are ill or unemployed, the social partnership often addresses internal and external stakeholders, for example employees, professional organisations, shareholders, politicians, etc. If the target group consists of internal stakeholders or employees, it is important to take the organisational level on which these stakeholders are placed into consideration. In a change context, it is for example relevant to address the nearest leader. The nearest leader is the one who can most successfully tell the employees "on the shop floor" what the change project means to their work (Petersen 2003).

In principle, the partnership can choose between different channels if it wishes to communicate with the employees in the private company. The channels can be oral or written. They can be personal or impersonal, one-way or two-way, active or passive, electronic or non-electronic, etc. The interaction can be characterized as multi-medial (and multimodal). In our case, the channels can be dominated either by the public or the private partner. We shall now look into a local and regional case example.

\section{Developing and implementing CSR in a dialogical process}

The description of the who, what and where of the dialogue establishes an image of the social partnership as a change agent in our perspective. A change agent is defined in studies of change as a project manager who supports the implementation of a change project and who 
displays a special commitment (Buchanan and Buddy 1992: 6). In our example, the social partnership supports the implementation of a model for social responsibility which in many ways will pave the way for behaviour changes in the organisation. John Kotter's (1997) normative "Eight-Stage Process of Creating Major Change" model can be used to throw light on the change process. Kotter's model is based on the understanding that change processes require leadership. The leader must go in front in organisational change processes and be visionary, energetic and proactive. Furthermore, the model is based on the idea of a "burning platform" as a necessary element in the establishment of a sense of urgency of change. Kotter's model is directly based upon this notion of urgency.

According to Kotter's model, the change agent must first establish a sense of urgency. Employees and others must understand that change is necessary. The establishment of this sense of urgency in connection with the communication of social projects, and in general of issues under the CSR headline, raises certain problems and is often mentioned as one of the major challenges companies are facing. This is true both for communicating with the external stakeholders of the company (Morsing 2003), and for the internal communication of CSR. For innovation projects in general, communication is very much about informing about the change process and helping the organisation to understand the logic and the need for changes (Hildebrandt et al. 1997: 117). Some of the questions raised by employees regarding social innovation projects are: What does it mean to me that my workplace has decided to employ a number of persons in special considerations jobs? What does it mean to me that my workplace has decided to reduce absence because of illness and for example conduct conversations with people who have been absent because of illness for a certain period of time? Is my job threatened? Does it mean something for my salary? Will I get new job functions? What are the intentions of the management?

It can be an advantage to answer some of these questions in cooperation with the public partner for example the municipality. The municipality is better equipped to tell the employees why society needs inclusive workplaces, and there will be no speculations as to the motives of the company. The fact is that it is not logical for a company operating on ordinary market terms to employ people with reduced working capability. The communication strategy can best be characterized indi- 
rect, as a third party is involved in the communication process (Schultz/ Morsing/Ulf Nielsen 2004).

In the following, I will give a practical example of how the development and communication/implementation of a model for social responsibility in a dialogical process may take place. John Kotter's eight-stage change process is used to inform the dialogical process i.e. to explain the contents and the function of the dialogue and the dialogical elements (Kotter 1996). The framework of the theoretical model proposed is illustrated in figure 2 .

\begin{tabular}{|l|l|}
\hline Dialogue structure & Change process (stages) \\
\hline A: Initiative & $\begin{array}{l}\text { The partnership (steering group) with the public } \\
\text { partner in front: presentation of the context for } \\
\text { Social Responsibility. }\end{array}$ \\
\hline B: Reaction & $\begin{array}{l}\text { The employees in the private company and other } \\
\text { stakeholders: identification and discussion of } \\
\text { crises, potential crises and essential possibilities. }\end{array}$ \\
\hline A: Evaluation/closing & $\begin{array}{l}\text { The partnership: thank you very much for your } \\
\text { contribution - and the future work. }\end{array}$ \\
\hline
\end{tabular}

$\mathrm{A}=$ the partnership, $\mathrm{B}=$ employees at management level (nearest manager) in the private company.

Figure 2: Dialogue-Change Model

Figure 2 consists of John Kotter's change model (Kotter 1997) in a simple dialogue structure (Roulet et al. 1985), here exemplified by the first stage, i.e. establishing a sense of urgency (see below). The idea is to show that the change process takes place in a dialogical process of involvement. The model outlines the role distribution and the stages in the process where an overall top-down approach, which is typical for change management processes, can be successfully supplemented with a bottom-up approach. It may, for example, be part of an "empowerment" strategy where the idea is to empower people to act and take responsibility in a new context. 


\subsection{Developing and implementing a model for social responsibility}

The development and the implementation of the project in my case example takes place in a dialogical process and can be divided into two phases: a development phase and an implementation phase.

\subsubsection{Developing the strategy}

The development of the strategy took place as indicated in example (4) in which the dialogue consisted of an exchange made up of three turns of talk (initiative, reaction and evaluation):

(4)

A: Initiative Opening seminar (whole day)

The project management (the public partner and the private partner), with the public partner in front, presented the context of social responsibility and invited employees (station managers and department managers in Falck in the county of Århus and project assistants in RevaCenter Århus Nord) and other stakeholders and asked them to identify and discuss crises, potential crises and essential possibilities.

B: Reaction Answers from the employees and the other stakeholders to the questions put forward to them.

A: Evaluation The project management closes the exchange: "Thank you very much for your participation”.

Example (4) shows how a sense of urgency (stage no 1 in Kotter's change model) is established in a dialogical process.

(5)

A: New initiative Working seminar no 1 (half day).

The project management presented a set of reference terms elaborated on the basis of input from the opening seminar and invited at the same time a more narrow circle of people (selected station managers and department managers in Falck in the county of Århus and selected project assistants in RevaCenter Århus Nord) to form four working groups composed across sectors and according to interests. Their task was to transform the terms of reference into a real course of action. 
B: Reaction Working seminar no 2 (half day).

The working groups delivered their respective contributions in the form of a draft model for job integration and job retention in Falck A/S in the county of Århus. They also made drafts for courses of action, a job creation catalogue and a communication plan (leaflets, after work gatherings, etc.).

A: Evaluation Steering group and sparring group meeting. The model was adopted with some minor modifications.

Example (5) demonstrates how visions and strategies are developed in a dialogical process (stage no 3 in Kotter's change model). The partnership has beforehand - and in another dialogical forum - assumed the responsibility for stage no 2, creating the guiding coalition. As examples numbers (4) and (5) show, the development of the project took place in a dialogical process consisting of two exchanges. The initiative in example no (4) paved the way for the initiative and the presentation of the terms of reference in example no (5).

\subsubsection{Implementing the strategy}

Also the implementation of the strategy took place in a dialogical process, exemplified by the following:

(6)

A: Initiative

Start-up seminar (whole day)

The project management with Falck A/S in front invited all station managers and department managers in Falck A/S in the county of Århus and all project assistants in RevaCenter Århus Nord to participate in the seminar. The purpose was to present the new model for Social Responsibility and to say that the model was now going to be tested in Falck A/S in the county of Århus. At the same time the partnership was willing to answer questions about how to use the model in practice. The working groups set up in the project were directly involved in the communication of the project.

B: Reaction

Testing the model in the workplace.

A: Evaluation Internal and external evaluation organized by the project management. The external report was financed by the Danish Ministry for Social Affairs (written report). 
Example (6) shows how the change vision is communicated and how a broad-based action is empowered in a dialogical process (stages 4 and 5 in Kotter's change model). Example (4) and example (5) paved the way for example (6). In example (4) and example (5) the public partner took the lead, whereas the company - and the guiding coalition - took the lead in example (6). The examples show that Kotter's change model can be used to explain the link between the exchanges. It enables focus on the contents or the function of the individual stages in the change process.

\section{The behaviour change process}

The change process I have described above went through two phases related to corporate strategy: a development phase and an implementation phase. The development phase consisted in many ways of the first four stages in Kotter's model. According to Kotter, these are stages which must be completed before continuing to stages 5-8. The message at the opening seminar was that Falck's decision to assume social responsibility was a necessary decision from a societal point of view. At the same time, it was a decision in line with the mission of the company. The background was new legislation on the follow-up of the municipalities in sickness benefit cases resulting in an increased pressure on the company. For example, Falck A/S in the county of Århus envisaged a complicated cooperation with 275 municipalities, each of them with individual practices. It was about the same time the Minister of social affairs formally asked the management of Falck participate in the Danish National Network of CEOs in order to support the vision of the Inclusive Labour Market. Like other companies, Falck felt a slight pressure from the public sector to take responsibility for groups of people outside the labour market. Social clauses were for example clear signals of the fact that Danish companies should assume greater social responsibilities if they were to have orders from the municipalities. Also, quotas as we know them from other countries might be the result if Danish companies did not assume responsibility for this group on a voluntary basis. A formalized cooperation with the public sector, here RevaCenter Århus Nord, would be the means by which the company could reduce the pressure, for example via an increased coordination in connection with sickness benefit cases. Furthermore, the vocational rehabilitation 
centre could contribute with knowledge about job retention and job integration - a knowledge which may be relevant from a bottom line perspective. How much would it cost to retain a rescuer by drawing on the expertise of the vocational rehabilitation centre, and how much money could the company save by not having to educate a new rescuer? (evaluation report by Hallundbæk and Madsbjerg 2002) (stage 1 in the change process).

Immediately after the first working seminar a group was set up in another dialogue forum which was sufficiently powerful to lead the change. The group consisted of selected station and department managers in Falck in the county of Århus (including shop stewards) and selected project assistants (primarily job consultants and social advisors with management responsibilities and/or a special professional expertise) in RevaCenter Århus Nord. These people formed together with the steering group four working groups set up across sectors according to professional specialities and/or interests. The working groups met regularly for a certain period of time and worked in practise as four teams (stage 2).

The task of the working groups was to develop the original vision presented by the steering group and to formulate strategies for the realization of the vision, such as proposing action points and communication activities (stage 3 ).

Moreover, the task of the working groups was to communicate the new vision and strategies by setting good examples of the behaviour expected of the other employees. Representatives of the working groups organized after-work gatherings, produced presentations at the start-up seminar, etc. (stage 4).

The start-up seminar marked in many ways the transition to stage 5 in Kotter's model. The announcement made by the management that the model was ready for testing made it possible to involve the whole organisation. The model was going to be tested in Falck in four counties. The expectation was that during the testing period the model would generate short-term wins (stage 6) so that after the end of the project period, it would be possible to consolidate the gains and implement more changes (stage 7). The time following the end of the project period showed that the model met the expectations, and the new ways of 
working are today implemented in the organisation of Falck as well as in the organisation of Jobcenter Århus Nord (stage 8).

It was characteristic for the process that the management (the partnership) were leading the two phases related to corporate strategy, i.e. the development phase and the implementation phase (stages 1 and 5) in close cooperation with the shop steward. In the other phases, there was a higher degree of involvement of the employees and the other stakeholders, i.e. a more sincere dialogue.

\section{Role distribution in the partnership}

In discussing the various roles in the partnership I will focus on only one interesting aspect, i.e. the communication of the message/the intentions versus the communication of the subject.

In example (4)-(6) above (A) is the social partnership consisting of the public partner and the private partner (the company). The voices of the two partners are not equally strong in the different initiatives. For example, the voice of the public partner is stronger than the voice of the private partner in example no (4) and example no (5), whereas the voice of the private partner is strongest in example (6). It is clear that example (4) and example (5) prepare or pave the way for example (6). It is necessary to develop the strategy before it can be implemented. In other words, the public partner paves the way for the implementation of the project. In example (4) the partnership (with the public sector in front) is responsible for communicating the vision and the message, i.e. that the company (management and employees) must take a social responsibility. In example (6) the partnership (with the private partner in front) is responsible for communicating the subject - a subject which has almost the form of a product (a model for job retention and job integration/recruitment).

From a theoretical communication perspective, what has happened is that the social partnership has made sure that the recipients have understood the message, i.e. have understood what the sender wants to obtain with his communication, before continuing the communication of the subject. Furthermore, the partnership has estimated that the public partner is most successful in communicating the message or the intention, whereas the private partner is most successful in communicating the subject or the specific product. 


\section{Conclusion}

In this article I have examined the role of dialogue in Danish public sector Corporate Social Responsibility (CSR) Communication. By means of a case study I have demonstrated that people working in the public sector, here government departments and local bodies, can use dialogue as a strategic tool which can lead to behaviour change and employer mobilisation. I have shown how the dialogue on CSR conducted in Denmark is initiated at a national level and pursued at a regional and local level in form of public-private or social partnerships. At the regional and local level the public actor and the employer have a clear role distribution when communicating CSR to employees and others. Based on my case study, I have argued that there may be a specific pattern in the way in which the partners distribute the roles between them. The public actor communicates the message/the intention, whereas the employer communicates the subject. There may also be a pattern in the way in which the partnership interacts with employees and other stakeholders. In close cooperation with the shop stewards, the partnership management leads the change in the initial phases, but involves the employees in other stages.

A structural analysis made within the framework of a dialogue analysis model conceived within linguistics has paved the way for the above analysis. I have shown that a typical dialogue structure is a relevant framework for analysing public sector CSR communication, here the development and implementation of a model for social responsibility. The structure supports the contents, which I have illustrated by means of Kotter's eight-step model of change. However, in order to make genuine structural and functional analyses of very long and complex dialogues conducted in organisational and cross-sector settings such as the dialogue on CSR between people working in the public sector (Government departments, local bodies and State agencies) on the one hand and employers on the other hand, more research is needed on how to delimit the constituents or the turns and how to establish the relations between these. Here, I have chosen the qualitative approach, but quantitative contributions could also assist in the process of highlighting cross-sector dialogues and further developing the theoretical dialogue-change model I have proposed as an alternative to how government departments, State agencies and local bodies can mobilize employers. 


\section{References}

Alrø, Helle/Kristiansen, Marianne (eds.) 2004: Dialog og magt i organisationer.Aalborg: Aalborg Universitetsforlag.

Andersen, Hanne Leth/Thomsen, Christa. Under peer review: Framing organisational dialogue: Dialogue in management and education. In Journal of Business Communication.

Andersen, Jørgen Goul/Pedersen, Jacob J. 2006. Continuity and change in Danish active labour market policy: 1990-2005. Paper prepared for international conference on Welfare State Change: Conceptualisation, Measurement and Interpretation, St. Restrup, Denmark, 13-15 January.

Bohm, David 1996: On Dialogue. London/New York: Routledge.

Bredgaard, Thomas 2004: Virksomhedernes sociale ansvar - fra offentlig politik til virksomhedspolitik. Ph.d. dissertation. Aalborg: Aalborg Universitet.

Brown, P./Levinson, S.C. 1987: Politeness: some universals in language usage.Newcastle upon Tyne: Cambridge University Press.

Buchanan, D./Boddy, D. 1992: The Expertise of the Change Agent. In International Encyclopedia of Communication. Oxford: Oxford University Press.

Carroll, Archie B. 1999: Corporate Social Responsibility. Evolution of a Definitional Construct. In Business \& Society. Vol. 38, no. 3, September, 268-295.

Christensen, L.T./Morsing, M. 2005: Bagom corporate communication. Copenhagen: Samfundslitteratur.

Damgaard, Bodil 2000: Kommunerne, virksomhederne og den aktive socialpolitik. Copenhagen: Socialforskningsinstituttet.

Ellinor, Linda/Gerard, Glenna 1998: Dialogue: Rediscover the Transforming Power of Conversation. John Wiley \& Sons, Inc.

European Commission 2001: Promoting a European framework for corporate social responsibility. Green Paper. Bruxelles: The European Commission.

Frandsen, F./Halkier, H./Johansen, W. 2002: Netvcerk: Introduktion til international erhvervskommunikation. Aarhus: Systime A/S.

Freeman, R. E. 1984: Strategic Management: A Stakeholder Approach. Boston MA: Pitman.

Freeman, R. E./Velamuri, S.R. 2006: A New Approach to CSR: Company Stakeholder Responsibility. In Kakabadse, A./Morsing, M. (Eds.), Corporate Social Responsibility: Reconciling Aspiration with Application. Palgrave MacMillan, 9-23.

Friedman, M. 1970: The Social Responsibility of Business is to Increase its Profits. In The New York Times Magazine. September 13.

Goffman, E. 1981: Forms of Talk. USA: University of Pennsylvania Press.

Grunig, J./Hunt, T. 1984: Managing Public Relations. New York: Holt, Rinehart and Winston, Inc. 
Hallundbæk, F./Madsbjerg, K. 2002: Den sociale platform - Falck A/S. Evaluering af de organisatoriske og driftsøkonomiske aspekter ved fastholdelse af medarbejdere samt udkast til ledelsesvcerktøj til vurdering af disse aspekter. Århus: Revacenter Århus Nord.

Hardis, J. 2004: Sociale partnerskaber. Copenhagen: Copenhagen Business School.

Hildebrandt et al. 1997: Fornyelse i virksomheder. Copenhagen: Børsen.

Holt, Helle 1998: En kortlcegning af danske virksomheders sociale ansvar. Copenhagen: Socialforskningsinstituttet.

Isaacs, William 1999: Dialogue and the Art of Thinking Together: A Pioneering Approach to Communicating in Business and in Life. New York: Doubleday.

Jackson, S./Jacobs, S. 1981: Structure of conversational argument: Pragmatic bases for the enthymeme. In Quarterly Journal of Speech 66, 251-65.

Jacobs, Scott/Jackson, Sally 1989: Building a Model of Conversational Argument. In Dervin, Brenda et al. (eds.): Rethinking communication, vol. 2, 153-71. Newbury Park, CA: Sage.

Kakabadse, N.K./C. Rozuel/L. Lee-Davies 2005: Corporate social responsibility and stakeholder approach: a conceptual review. In International Journal of Business Governance and Ethics, Vol. 1, No. 4, 277-302.

Kerbrat-Orecchioni, C. 1990: Les interactions verbales. 1. Paris: Armand Colin.

Klausen, Klaudi K. 2001: Skulle det være noget særligt? Copenhagen: Børsens Forlag.

Knudsen, Jette Steen 2006: The global Reporting Initiative in Denmark: Emperor's New Clothes or Useful Reporting Tool? In Kakabadse, Andrew/Morsing, Mette/ Lenssen, Gilbert: Corporate Social Responsibility. Reconciling Aspiration with Application. N.Y.: Palgrave MacMillan.

Kotter, J. 1996: Leading Change. Boston: Harvard Business School Press.

Martin, Cathie Jo 2006 : Corporatism in the Post-Industrial Age : Employers and Social Policy in the Little Land of Denmark. In Campbell, John, Hall, John and Pedersen, Ove Kaj (eds.), National Identity and a Variety of Capitalism: the Danish Case. Montreal, CA: McGill Queens University Press in association with Djøf-Forlagene, 271-294.

Morsing, M. 2003: Conspicuous Responsibility: Communicating Responsibility - To Whom? In Morsing, M./Thyssen, C. (eds.), Corporate Values and Responsibility. Copenhagen: Samfundslitteratur, pp. 145-154.

Nelson, J./Zadek, S. 2000: Partnership Alchemy. New Social Partnerships in Europe. Copenhagen: The Copenhagen Centre.

Nølke, Henning/Adam, J.-M. (éds) 2000 : Approches modulaires : de la langue au discours, Lausanne/Paris : Delachaux et Niestlé.

Petersen, H. 2003: Forandringskommunikation. Copenhagen: Samfundslitteratur.

Petersen, V.C. 2004: Hinsides regler. Copenhagen: Børsens Forlag. 
Roulet, E. et al. 1985: L'articulation du discours en francais contemporain. Bern: Peter Lang.

Sacks, H./Schegloff, E.A./Jefferson, G. 1978: A simplest systematics for the organisation of turn taking for conversation. In Schenkein, J. (ed.), Studies in the Organisation of Conversational Interaction, 7-56. Academic Press.

Schultz, M./Morsing, M./Ulf Nielsen, K. 2004: Kommunikationsstrategi for Social Ansvarlighed[online].http://www.reputationinstitute.com/international/articles/ Kom_27ED13.pdf(1st September 2006).

Sepstrup, Preben 2006: Tilrettelceggelse af information. Kommunikations- og kampagneplanlægning. Aarhus: Academica. 3. udgave.

Thomsen, C. 2000: Stratégies d'argumentation et de politesse dans les conversations d'affaires. Bern: Peter Lang.

Waddock, S. 2004: Parallel Universes: Companies, Academics, and the Progress of Corporate Citizenship. In Business and Society Review 109(1), 5-42.

Wymer, Walter W., Jr./Samu, S. (eds) 2003: Nonprofit and Business Sector Collaboration: Social Enterprises, Cause-Related Marketing, Sponsorships, and Other Corporate-Nonprofit Dealings. New York: Best Business Books. 